\title{
Current Knowledge of the Entomopathogenic Fungal Species Metarhizium flavoviride Sensu Lato and Its Potential in Sustainable Pest Control
}

\author{
Franciska Tóthné Bogdányi ${ }^{1}{ }^{\oplus}$, Renáta Petrikovszki ${ }^{2}{ }^{\circledR}$, Adalbert Balog ${ }^{3}$, \\ Barna Putnoky-Csicsó ${ }^{3}$, Anita Gódor ${ }^{2}$, János Bálint ${ }^{3, *}$ and Ferenc Tóth ${ }^{2, *}$
}

1 FKF Nonprofit Zrt., Alföldi str. 7, 1081 Budapest, Hungary; t.bogdanyi.franciska@gmail.com

2 Plant Protection Institute, Faculty of Agricultural and Environmental Sciences, Szent István University, Páter Károly srt. 1, 2100 Gödöllő, Hungary; petrencsi@gmail.com (R.P.); agodor@gmail.com (A.G.)

3 Department of Horticulture, Faculty of Technical and Human Sciences, Sapientia Hungarian University of Transylvania, Allea Sighișoarei 1C, 540485 Targu Mures/Corunca, Romania; adalbert.balog@ms.sapientia.ro (A.B.); csicsobarni@gmail.com (B.P.-C.)

* Correspondence: balintjanos@ms.sapientia.ro (J.B.); toth.ferenc@mkk.szie.hu (F.T.); Tel.: +40-744-782-982 (J.B.); +36-30-5551-255 (F.T.)

Received: 17 July 2019; Accepted: 31 October 2019; Published: 2 November 2019

\begin{abstract}
Fungal entomopathogens are gaining increasing attention as alternatives to chemical control of arthropod pests, and the literature on their use under different conditions and against different species keeps expanding. Our review compiles information regarding the entomopathogenic fungal species Metarhizium flavoviride (Gams and Rozsypal 1956) (Hypocreales: Clavicipitaceae) and gives account of the natural occurrences and target arthropods that can be controlled using $M$. flavoviride. Taxonomic problems around M. flavoviride species sensu lato are explained. Bioassays, laboratory and field studies examining the effect of fermentation, culture regimes and formulation are compiled along with studies on the effect of the fungus on target and non-target organisms and presenting the effect of management practices on the use of the fungus. Altogether, we provide information to help conducting basic studies, and by pointing out relatively uncharted territories, help to set new research areas.
\end{abstract}

Keywords: fermentation; formulation; field crops; greenhouse crops; sustainable management; pest control

\section{Introduction}

As an alternative to chemicals, the use of mycoinsecticides is considered an ecologically friendly method in the control of arthropod pests. More and more fungal strains and isolates are on their way to becoming commercial products available for the market; their use in sustainable pest control is under expansion. Members of the Metarhizium genus (Sorokin) seem to have the potential to become successful entomopathogenic agents. Among them, Metarhizium anisopliae (Metschnikoff) Sorokin (Hypocreales: Clavicipitaceae) stands out both in the volume of related scientific research, including review articles, and in the use in organic pest control [1]. Some other members of the genus have also been frequently cited. To mention some of the other entomopathogens that have been researched, M. brunneum (Petch) was found as a promising candidate against Coleopteran pests (wireworms, larvae of Elateridae) in potatoes and other vegetables [2,3] and M. brunneum and M. robertsii (J.F. Bischoff, Rehner and Humber) are also on their way to become commercial products against the soil-dwelling life stages of Coleopteran and Dipteran pests (cabbage fly, Delia radicum, Linnaeus and the crane fly, Tipula paludosa, Meigen) in various crops [4-6]. In 2017, a compilation [7] suggested that although its 
successful application needs further studies and trials, Metarhizium rileyi ((Farlow) Kepler, S.A. Rehner and Humber) may also have strong potential to become a commercial product as it was found effective against Lepidopteran pests. Our targeted taxon, $M$. flavoviride has a record of being available as a registered product against scarab larvae in Australia [8-11], but there is no consensus on the taxonomic status of the active microbial agent used. The first two sources citing Copping (2004) refer to the agent as M. flavoviride var. flavoviride, and the latter two name the agent $M$. flavoviride. Indeed, the literature available on $M$. flavoviride sensu lato raises questions of taxonomic nature, and while there is an array of tests and investigations on, Metarhizium flavoviride sensu lato, the conditions of its use remain relatively unmapped, and its potential has not yet been fully studied and discovered. Indeed, M. flavoviride is one of the most rarely investigated and documented fungal entomopathogens [12-14].

Therefore, the present paper aims to provide a guide to help readers seeking potential agents in sustainable pest control navigate within and understand the state of present-day knowledge of M. flavoviride isolates and strains. We collected and sorted scientific information on M. flavoviride sensu lato with the purpose to guide entomologists within the selected literature on this fungus used under different conditions and against different pests. The most important host species and circumstances of use regarding $M$. flavoviride sensu lato are also presented.

\section{Literatures on the Genus Metarhizium}

We explored scientific papers from over 70 websites. The most frequent sources of information were online research collections including SpringerLink, ScienceDirect, Taylor and Francis Online, Wiley Online Library, ResearchGate, PubMed, Scientific Electronic Library Online, BioOne Complete, Web of Science and also online journals and databases [15-24]. Working through the various sections of our manuscript, we selected simple keywords to identify scientific papers to match the main topic of the section. While "Metarhizium flavoviride" was always an identifier, other keywords varied according to topic. We arranged the information in a sequence that may reflect the approach of a researcher or extension agent for whom M. flavoviride is a relatively new area: going from basic towards more specialized information regarding the potential and actual application. Our review starts with the earliest accounts of the species including its natural occurrence and the range of natural hosts. This is followed by studies on the impact of formulation types, culture media on the use of the various strains and isolates on bioassays, and studies carried out in greenhouses, pot experiments or in fields; regarding the effect of management practices are compiled. Altogether more than 110 articles including reviews, experimental and observational studies were compiled.

\section{A Short Introduction to the Genus Metarhizium}

Currently the genus Metarhizium is positioned within the Kingdom of Fungi (Mycota), Division Ascomycota, Subdivision Pezizomycotina, Class Sordariomycetes, Subclass Hypocreomycetidae, Order Hypocreales, Family Clavicipitaceae [19].

Members of the genus are frequently isolated worldwide under all types of climate conditions, from the artic to tropical regions, from soil samples of various soil types, and found on a multitude of arthropod taxa [25-28]. One possible explanation for the ubiquity of the genus is their small and hydrophobic conidia that can be easily transported by the movement of the wind (8). The greenish conidial growth is one of the main general morphological features of the genus [27], hence the initial name of the disease its members cause- 'green muscardine' [29]. The conidiophores have branch formations that may vary from species to species, and the phialides that may have various shapes may also be single or multiplied [12]. Their facultative saprophytic lifestyle allows them to attack arthropods and grow as a parasite on their bodies. In the absence of a suitable host, members of this genus, due to their labile metabolism can live freely within the rhizosphere of plants or survive on non-living particles within the soil $[9,12]$. 


\section{Questions of Taxonomy and Identification Issues}

We understand that the taxonomy of fungal entomopathogens evolved from relying on morphological traits to using molecular traits [30], but as science advances, so has to progress the concept of species as well [31].

The genus Metarhizium is a genetically diverse taxon, and the color of the colony, the dimension and measurements of the conidia of different species are not reliable identification factors [32,33]. To some success, simple identification measures have been used with some success: an earlier study suggested distinguishing between M. anisopliae and M. flavoviride based on the difference in the homogeneity of blastophores, as the blastophores of $M$. flavoviride isolates were found more homogenous when compared to those of $M$. anisopliae [34]. Further, a recent attempt to simplify the identification of species or species complexes by evaluating certain isolates on their heat-tolerance and cold activity has been successful in the case of M. anisopliae var. anisopliae, M. anisopliae var. acridum and two isolates of the M. flavoviride species complex [35].

Nevertheless, diversity within an isolate makes identification difficult: morphological features of the same isolate is influenced by the age of culture, the substrate the culture is kept on, and on certain environmental conditions like temperature [29,36].

Around the turn of the century, as biochemical and molecular studies have become more and more used and accepted, papers have begun to point out that some, if not almost all of the isolates listed on the basis of morphological features as M. flavoviride or $M$. anisopliae, especially those that used Acridiid target species are actually M. acridum [36-38].

Research papers since the first reassessment of the genus based on molecular phylogenetics [29] have come to the agreement that the most accurate delimitation is based on molecular analysis, and the designation of species is best based on definitive genetic markers such as the random amplified polymorphic DNA $(R A P D)$ markers and the nucleotide sequences of the internal transcribed spacer (ITS) region $[14,25,26,32,39]$.

ITS-sequence phylogenetic analysis and multigene phylogenetic methods have laid a solid foundation for one of the latest descriptions of the M. anisopliae and M. flavoviride complexes [27,40]. At the same time, the definition of species is an inconclusive matter of taxonomic debates. When the definition of evolutionary units is unreliable, the relationship between two specimens or two taxa also becomes unreliable. This makes the concept of species a hypothesis, and therefore misleading, because we hardly ever have the chance to test whether two specimens belong to the same species [41]. This is especially the case in microbiology, where the subject of studies are isolates, not species, which questions the relevance of the species definition of the Linnaean taxonomy [31].

The concept of a nominal taxon, and therefore, nominal species indicates that when a taxon has a name attached to it, and references are made to it by that name regardless of that name being accepted or not, that name defines the taxon in question [42]. A nominal species is therefore a type of taxon below genus level that is defined by its name.

Some argue that the traditional definition of species is not applicable to members of the genus $[27,29]$, and morphospecies comprise a collection of morphologically identical, but separate species $[27,43]$. These "cryptic" species may have different ecological roles, physiological properties and environmental preferences [43,44], but it is also possible that some of these cryptic species within a morphospecies differ from the rest of the species of the genus and form a group by having the same ecological and environmental characteristics [43]. For the purposes of our study we applied morphospecies as described in [43], because we wanted to map the collection of knowledge about a biological control agent.

\section{The Species Spectrum of the Genus Metarhizium}

Based on comprehensive species lists of the genus up to 2014, a phylogenetic survey of isolates conducted in 2017, and on recent reports describing new species, we provide a compilation that contains members (species and variations) of the Metarhizium genus (Table 1). 
Table 1. Alphabetical species list of the Metarhizium genus. The first column presents the recent name of the taxon and references. The second column contains the most recent former name (and a reference, where applicable). $\mathrm{X}=$ Species of the $M$. flavoviride species complex (MFSC).

\begin{tabular}{|c|c|c|}
\hline Name of Species & Former Name & MFSC \\
\hline $\begin{array}{l}\text { Metarhizium acridum (Driver and Milner) J.F. Bisch., Rehner } \\
\text { and Humber stat. nov. }[25,27]\end{array}$ & $\begin{array}{l}\text { Metarhizium anisopliae var. } \\
\text { acridum Driver and Milner [29] }\end{array}$ & \\
\hline \multicolumn{3}{|l|}{ Metarhizium album [29] } \\
\hline \multicolumn{3}{|l|}{$\begin{array}{l}\text { Metarhizium alvesii Lopes, Faria, Montalva and Humber sp. } \\
\text { nov. [45] }\end{array}$} \\
\hline \multicolumn{3}{|l|}{ Metarhizium anisopliae (Metschn.) Sorokīn $[12,25,27]$} \\
\hline \multicolumn{3}{|l|}{ Metarhizium anisopliae var. anisopliae [29] } \\
\hline \multicolumn{3}{|l|}{$\begin{array}{l}\text { Metarhizium anisopliae var. majus [29] syn. Metarhizium } \\
\text { anisopliae var. major (J.R. Johnst.) M.C. Tulloch [46] }\end{array}$} \\
\hline \multicolumn{3}{|l|}{$\begin{array}{l}\text { Metarhizium atrovirens (Kobayasi and Shimizu) Kepler, S.A. } \\
\text { Rehner and Humber, comb. nov. [12] }\end{array}$} \\
\hline Metarhizium bibionidarum O. Nishi, H. Sato, sp. nov. [14] x & & $x$ \\
\hline $\begin{array}{l}\text { Metarhizium blattodeae Montalva, Humber, Collier and Luz, sp. } \\
\text { nov. [47] x }\end{array}$ & & $\mathrm{x}$ \\
\hline $\begin{array}{l}\text { Metarhizium brasiliense Kepler, S.A. Rehner and Humber, sp. } \\
\text { nov. [12] }\end{array}$ & $\begin{array}{l}\text { Metarhizium flavoviride Type E } \\
\text { [29] x }\end{array}$ & \\
\hline \multicolumn{3}{|l|}{$\begin{array}{l}\text { Metarhizium brittlebankisoides (Zuo Y. Liu, Z.Q. Liang, Whalley, } \\
\text { Y.J. Yao and A.Y. Liu) Kepler, S.A. Rehner and Humber, comb. } \\
\text { nov. [12] }\end{array}$} \\
\hline \multicolumn{3}{|l|}{ Metarhizium brunneum Petch $[25,27]$} \\
\hline \multicolumn{3}{|l|}{$\begin{array}{l}\text { Metarhizium campsosterni (W.M. Zhang and T.H. Li) Kepler, S.A. } \\
\text { Rehner and Humber, comb. nov. [12] }\end{array}$} \\
\hline \multicolumn{3}{|l|}{$\begin{array}{l}\text { Metarhizium carneum (Duché and R. Heim) Kepler, S.A. Rehner } \\
\text { and Humber, comb. nov. [12] }\end{array}$} \\
\hline \multicolumn{3}{|l|}{ Metarhizium cylindrosporum Q.T. Chen and H.L. Guo [12] } \\
\hline \multicolumn{3}{|l|}{$\begin{array}{l}\text { Metarhizium dendrolimatilis Z.Q. Liang, W.H. Chen, Y.F. Han } \\
\text { and D.C. Jin, sp. nov. [48] }\end{array}$} \\
\hline M. flavoviride (Gams and Rozsypal) [25] x & & $x$ \\
\hline Metarhizium flavoviride var. flavoviride [29] x & & $X$ \\
\hline Metarhizium frigidum J. Bisch. et S. A. Rehner, sp. nov. [40] x & & $X$ \\
\hline \multicolumn{3}{|l|}{$\begin{array}{l}\text { Metarhizium globosum J.F. Bisch., Rehner and Humber sp. nov. } \\
{[25,27]}\end{array}$} \\
\hline \multicolumn{3}{|l|}{$\begin{array}{l}\text { Metarhizium granulomatis (Sigler) Kepler, S.A. Rehner and } \\
\text { Humber, comb. nov. [12] }\end{array}$} \\
\hline $\begin{array}{l}\text { Metarhizium guizhouense Q.T. Chen and H.L. Guo, anamorph of } \\
\text { M. taii }[25,27]\end{array}$ & $\begin{array}{l}\text { Metarhizium taii Z.Q. Liang } \\
\text { and A. Y. Liu }\end{array}$ & \\
\hline \multicolumn{3}{|l|}{$\begin{array}{l}\text { Metarhizium guniujiangense (C.R. Li, B. Huang, M.Z. Fan and } \\
\text { Z.Z. Li) Kepler, S.A. Rehner and Humber, comb. nov. [12] }\end{array}$} \\
\hline \multicolumn{3}{|l|}{$\begin{array}{l}\text { Metarhizium indigoticum (Kobayasi and Shimizu) Kepler, S.A. } \\
\text { Rehner and Humber, comb. nov. [12] }\end{array}$} \\
\hline \multicolumn{3}{|l|}{$\begin{array}{l}\text { Metarhizium khaoyaiense (Hywel-Jones) Kepler, S.A. Rehner and } \\
\text { Humber, comb. nov. [12] }\end{array}$} \\
\hline $\begin{array}{l}\text { Metarhizium koreanum Kepler, S.A. Rehner and Humber, sp. } \\
\text { nov. [12] x }\end{array}$ & & $x$ \\
\hline
\end{tabular}


Table 1. Cont.

\begin{tabular}{|c|c|c|}
\hline Name of Species & Former Name & MFSC \\
\hline \multicolumn{3}{|l|}{$\begin{array}{l}\text { Metarhizium kusanagiense (Kobayasi and Shimizu) Kepler, S.A. } \\
\text { Rehner and Humber, comb. nov. [12] }\end{array}$} \\
\hline $\begin{array}{l}\text { Metarhizium lepidiotae [27] (Driver and Milner) J.F. Bisch., } \\
\text { Rehner and Humber stat. nov. }[25,27]\end{array}$ & $\begin{array}{l}\text { Metarhizium anisopliae var. } \\
\text { lepidiotae Driver and Milner (as } \\
\text { Metarhizium anisopliae var. } \\
\text { lepidiotum) [29] }\end{array}$ & \\
\hline $\begin{array}{l}\text { Metarhizium majus (J.R. Johnst.) J.F. Bisch., Rehner and } \\
\text { Humber stat. nov. }[25,27]\end{array}$ & $\begin{array}{l}\text { Metarhizium anisopliae var. } \\
\text { major (J.R. Johnst.) M.C. } \\
\text { Tulloch [46] }\end{array}$ & \\
\hline \multicolumn{3}{|l|}{$\begin{array}{l}\text { Metarhizium marquandii (Massee) Kepler, S.A. Rehner and } \\
\text { Humber, comb. nov. [12] }\end{array}$} \\
\hline \multicolumn{3}{|l|}{$\begin{array}{l}\text { Metarhizium martiale (Speg.) Kepler, S.A. Rehner and Humber, } \\
\text { comb. nov. [12] }\end{array}$} \\
\hline $\begin{array}{l}\text { Metarhizium minus (Rombach, Humber and D.W. Roberts) } \\
\text { Kepler, S.A. Rehner and Humber, comb. et stat. nov. [12] x }\end{array}$ & $\begin{array}{l}\text { Metarhizium flavoviride var. } \\
\text { minus Rombach, Humber and } \\
\text { D.W. Roberts [29] x }\end{array}$ & $x$ \\
\hline $\begin{array}{l}\text { Metarhizium novozealandicum Kepler, S.A. Rehner and Humber, } \\
\text { comb. et stat. nov. [12] }\end{array}$ & $\begin{array}{l}\text { Metarhizium flavoviride var. } \\
\text { novozealandicum Driver and R.J. } \\
\text { Milner [29] }\end{array}$ & \\
\hline \multicolumn{3}{|l|}{$\begin{array}{l}\text { Metarhizium owariense (Kobayasi) Kepler, S.A. Rehner and } \\
\text { Humber, comb. nov. [12] }\end{array}$} \\
\hline \multicolumn{3}{|l|}{$\begin{array}{l}\text { Metarhizium owariense f. viridescens (Uchiy. and Udagawa) } \\
\text { Kepler, S.A. Rehner and Humber, comb. nov [12] }\end{array}$} \\
\hline $\begin{array}{l}\text { Metarhizium pemphigi (Driver and R.J. Milner) Kepler, S.A. } \\
\text { Rehner and Humber, comb. et stat. nov. [12] x }\end{array}$ & $\begin{array}{l}\text { Metarhizium flavoviride var. } \\
\text { pemphigi Driver and R.J. Milner } \\
\text { [29] x }\end{array}$ & $x$ \\
\hline \multicolumn{3}{|l|}{ Metarhizium pingshaense Q.T. Chen and H.L. Guo $[25,27]$} \\
\hline $\begin{array}{l}\text { Metarhizium purpureogenum O. Nishi, S. Shimizu, H. Sato, sp. } \\
\text { nov. [14] x }\end{array}$ & & $x$ \\
\hline \multicolumn{3}{|l|}{$\begin{array}{l}\text { Metarhizium pseudoatrovirens (Kobayasi and Shimizu) Kepler, } \\
\text { S.A. Rehner and Humber, comb. nov. [12] }\end{array}$} \\
\hline \multicolumn{3}{|l|}{$\begin{array}{l}\text { Metarhizium rileyi (Farl.) Kepler, S.A. Rehner and Humber, } \\
\text { comb. nov. [12] }\end{array}$} \\
\hline \multicolumn{3}{|l|}{$\begin{array}{l}\text { Metarhizium robertsii J.F. Bisch., Rehner and Humber sp. nov. } \\
{[25,27]}\end{array}$} \\
\hline \multicolumn{3}{|l|}{ Metarhizium taii Z.Q. Liang and A.Y. Liu [12] } \\
\hline \multicolumn{3}{|l|}{$\begin{array}{l}\text { Metarhizium yongmunense (G.H. Sung, J.M. Sung and } \\
\text { Spatafora) Kepler, S.A. Rehner and Humber, comb. nov. [12] }\end{array}$} \\
\hline \multicolumn{3}{|l|}{$\begin{array}{l}\text { Metarhizium viride (Segretain, Fromentin, Destombes, Brygoo } \\
\text { and Dodin ex Samson) Kepler, S.A. Rehner and Humber, comb. } \\
\text { nov. [12] }\end{array}$} \\
\hline $\begin{array}{l}\text { Metarhizium viridulum (Tzean, L.S. Hsieh, J.L. Chen and W.J. } \\
\text { Wu) B. Huang and Z.Z. Li [12] }\end{array}$ & & \\
\hline
\end{tabular}

\section{A Short Literature Overview of the M. flavoviride Species Complex}

Following the initial detection of the genus Metarhizium, Gams and Rozsypal (at times misspelled by authors as Rozypal, Roszypal or Rozsypa) described a new species by the name $M$. flavoviride in 1973 [49]. In 1976 M. anisopliae, its two varieties and M. flavoviride were recognized as species of the 
genus. The distinction between the two species was based only on the shape of conidia and the color of the colonies [46].

The spectrum of the M. flavoviride species complex was gradually built up. In 1986, Mf var. flavoviride and var. minus was acknowledged by Rombach et al. [29,39]. In 2000, based on molecular analysis of isolates, the characteristics of $M$. flavoviride var. flavoviride were found only in the original strain collected and conserved by the original authors of the species, and $M f$. var. novozealandicum and $M f$ var. pemphigum were introduced as new variations of the main species $[29,39]$.

In 2005, there were still only three species (M. anisopliae, M. album and M. flavoviride) recognized within the genus, and suggestions had been made to unify them as M. anisopliae [26]. However, the following years seem to have witnessed an opposite trend: it appears that the number of separate species is rising. The frigidum variation of the Ma-complex was found to have a closer relationship with the M. flavoviride complex [29], and in 2006 was designated as a distinct species, with the name M. frigidum [40]. A new species, with a name that refers to the geographical origin of the first isolate was described in 2014 as M. koreanum [12]. Advances in molecular tests have led to former variations being elevated to species level in 2014 as M. minus, M. novozealandicum and M. pemphigi [12]. The location of M. novozealandicum within the genus has recently been challenged, and this species has been transferred outside the Metarhizium flavoviride species complex MFSC [14]. An isolate that was found a member of the MFSC in 2000 as Mf Type E [29] was assigned species level as M. brasiliense as well [12]. In 2016, a new species, M. blattodea was described from Brazil [47]. Recent studies In Japan have expanded the limits of the Mf species complex by adding two new species described as M. bibionidarum, which was isolated from Japanese and French soils alike, and was found to have a close relationship with M. pemphigi, and M. purpureogenum, a remote species with unique conidial shape within the complex, where the name refers to the distinct pigment production of the species [14].

\section{Natural Occurrences and Natural Hosts of M. flavoviride}

Metarhizium flavoviride was first observed in Europe in the late 1950s on various life stages (larvae and pupae) of two curculionid beetles: Ceutorrhynchus macula-alba Herbst (the poppy capsule weevil) and C. albovittatus Germar [49]. According to current classification, the two Coleopteran beetles belong, along with N. smyrnensis, to the genus Neoglocianus [16]. In 1969 the same fungus was found in agricultural soils in Northern Europe in Germany and the Netherlands [49].

The species was first isolated in another continent, Australia, from a native Orthopteran, Austracris guttulosa Walker in 1979 [36]. The first African account of M. flavoviride dates from the early 1990s when the presence of the fungus was detected on heavily infected, but still alive Zonocerus variegatus Linnaeus and Hieroglyphus daganensis Krauss, two local Orthopteran pests in Southern Benin, Africa [50,51]. An intensive study of 350 cadavers of Locusta migratoria migratorioides Reiche and Fairmaire (Orthoptera: Acrididae) in the south western part of Madagascar resulted in finding M. flavoviride in two of the specimens [34]. The second time a M. flavoviride isolate was recorded in Australia was in 1997 [36], and a strain of the species was first detected on an Orthopteran host in the Revillagigedo Islands, México [52]. Natural occurrences of epizootics in Africa were recorded in the late 1990s affecting two orthopterans, Ornithacris cavroisi Finot in Niger and Diabolocatantops axillaris Burmeister in Chad [51]. In 1997, Mietkiewski et al. examined the presence of fungal entomopathogens in cultivated fields and recorded a rare occurrence of $M$. flavoviride within barley fields [53].

Investigations for the presence of $M$. flavoviride and the frequency of fungal infections were carried out for three consecutive years in Northern Benin, Africa in the 1990s. The occurrence of the fungus on sampled areas was low (1.6\% to $2.6 \%$ ). The dominant hosts of the fungus were orthopterans, mostly those living within the soil or in the surface of the soil (Acrotylus blondeli Saussure, C. senegalensis, now: Oedaleus senegalensis Krauss, Pyrgomorpha cognata Krauss and member of the genus Stenohippus Uvarov) and those living on trees (Cryptocatantops haemorrhoidalis Krauss, Catantops stramineus Walker, Diabolocatantops axillaris Thunberg and Harpezocatantops stylifer Krauss). The rate of infected hosts was less than $3.2 \%$. The study concluded in finding no significant differences between the frequency of 
infections between years or location. A unique observation of this study is the reddish hue of the conidial mass of $M$. flavoviride on the surface of arthropod cadavers before sporulation [54].

In a 2005 study conducted on viable microorganisms found in a lignite excavation site in Slovakia [55] the presence of $M$. flavoviride was rendered likely by morphological and genetic sequence analysis. Meyling and Eilenberg (2006) were looking for entomopathogenic fungi on different agricultural habitats and while M. flavoviride was found to be the third most frequent species in the field in both years, it was hardly collected from adjacent hedgerows [56].

A M. flavoviride var. flavoviride isolation was reported as a novel isolate from the Philippines, Southeast Asia in 2011. A diseased Lepidopteran instar of Helicoverpa armigera Hübner (Lepidoptera: Noctuidae) was detected with clear signs of fungal infection. Morphological characterization designated the isolates grown on the cadaver as the genus Metarhizium and molecular analysis (DNA sequencing) confirmed the species status: it was a M. flavoviride var. flavoviride isolate [57]. In the same year, a thorough investigation involved root sampling of plants of different taxa in the USA, North America. Using an adjusted version of the original Galleria bait method by Zimmerman [58], the fungal composition of the root zone of strawberry (Rosaceae), blueberry (Ericaceae), grape (Vitaceae) and various pines (Pinaceae) yielded four Metarhizium species. Molecular phylogenetic identification revealed the presence of $M$. flavoviride var. pemphigi, a member of the M. flavoviride species complex, within the root zone of strawberries and pines [59].

The Galleria bait method applied to soil samples collected in Korea, and the subsequent DNA extraction and sequence analysis resulted in confirming the presence of $M$. flavoviride var. pemphigum (sic) [60]. When soil samples were taken from a field and its hedgerow in Denmark and were evaluated for the distribution and abundance of Metarhizium species by using Tenebrio molitor Linnaeus (Coleoptera: Tenebrionidae) larvae as bait, the presence of $M$. flavoviride was proven both in the field and in the hedgerow both by morphological and molecular tests [61]. In 2015, the soil bait method was successful in finding isolates for a study that combined root and soil sampling of two crop fields (winter wheat and winter oilseed rape) and a grass pasture that had been set aside for two decades in Denmark.

In 2015, genetic characterization studies performed on fungal isolates obtained from fungus infected larvae of the coleopteran Amphimallon solstitiale Linnaeus (Coleoptera: Scarabaeidae) collected from roots of various plants in North Eastern Turkey revealed that the hosts were infected by M. flavoviride [62].

The modified Galleria bait method, using Tenebrio molitor larvae resulted in M. flavoviride being the predominant species in the investigated areas. Morphological markers such as conidial colour and dimensions suggested $M$. flavoviride, which was validated by PCR amplification and sequencing analysis as well. It turned out that over $89 \%$ of the isolates belonged to $M$. flavoviride, and an amplified fragment length polymorphism (AFLP) analysis revealed high diversity within the species [13].

The occurrence of $M$. flavoviride in a hydrothermal cave was first reported in 2017. The presence of the species was confirmed by morphological, trophic and physiological observations, and the conventional tests were accompanied and confirmed by analysing molecular markers as well [63]. A 2018 study based on Tenebrio molitor larvae as bait investigating soil samples collected in Korea found fungal isolates belonging to 12 genera and 29 species, M. flavoviride being one of them [8].

The natural occurrence of $M$. flavoviride sensu lato has been documented from a wide range of natural environments, but this does not imply that the taxon can be isolated from all soil samples with the same success. In their argument supported by contemporary literature, [60] presents their finding that in undisturbed, permanent cultures such as riparian areas, natural vegetation is more likely to supply entomopathogenic fungi (and M. flavoviride in particular) in higher percentages than agricultural areas. Furthermore, no clear connection was proven between the genetic composition of Metarhizium isolates found in agricultural fields and the type of the crop [64]. Furthermore, it continues to be the subject of further examination whether yields are similar between lands under permaculture or conventional agricultural management. 
As researchers continue to seek biological alternatives to chemical management protocols, more and more type of habitats and even microhabitats are expected to be investigated for the presence of fungal entomopathogens and of $M$. flavoviride. This expansion of knowledge about the ecology of the taxon will contribute to its more to its more frequent, and possibly more successful use in biological control.

\section{Effect of Conditions during Fermentation, Cultivation, Culture Regimes on the Performance of M. flavoviride}

Conditions of fermentation and the composition of the culture medium may significantly influence the efficacy of $M$. flavoviride strains. The first studies tested the effect of medium content on conidial production and concentrations including mortality of target pests, and secondary sporulation. According to the results, the cumulative mortality of Zonocerus variegatus L. (Orthoptera: Pyrgomorphidae) increased and the fungal pathogen was highly effective even in samples taken 8 days after spraying with $M$. flavoviride as an oil formulated product $[50,65]$.

Other studies tested the effects the length of storage, and temperature had on M. flavoviride [66]. When storage involved the addition of powder and/or fatty acids, germination percentages were positively influenced by carbon:nitrogen [C:N] ratio, age of culture (time passed after inoculation), air moisture and storage method (dry powder or in oil) [67-69].

Conidial production, morphological features, fungal pathogenicity, conidial growth, production of conidia and blastospores under growing media also increased when $\mathrm{N}$ sources in the medium increased and the C:N ratio also had a positive effect on the pathogenicity of $M$. flavoviride [70,71]. It appears that although an array of potential components of fermentation and culture regimes have been investigated over time, the time frame in which these studies were done is a relatively narrow one, and the field has been somewhat neglected in the past two decades. Therefore, the impact of fermentation on the adaptability and pathogenicity of $M$. flavoviride sensu lato still awaits more detailed tests.

\section{Effect of Formulation on the Performance of M. flavoviride}

To successfully shift a fungal candidate from the laboratory to the greenhouse and from the relatively safe and controlled environment of protected production to circumstances found in arable fields, mainly depends on the way the potential pest management agent itself is protected. This protection might be supplied through the appropriate formulation of the product [72].

Alternative formulations (mineral, natural oil and/or water water-based formulations) were tested under various conditions including different wavelength of solar radiation, age of cultures, addition of oils and/or sunscreens $[66,67,73-75]$.

As a general observation, a definite positive effect of natural oil formulation was recorded. The effects of formulation may have been expressed in different characteristics of the fungus including conidial growth, viability and potential to cause mortality to target organisms, durability or resistance to certain environmental factors. One may also notice that while this area was intensively tested in the 1990s, less research has been conducted since that time. One inevitable challenge formulation faces when trying to enhance the efficiency of the fungal entomopathogen is the presence of ultra-violet light among unprotected field conditions that have a significant negative effect on $M$. flavoviride germination [76].

Caged field trials testing the efficacy of $M$. flavoviride against target organisms such as Ostrinia nubilalis, Sesamia cretica and Chilo agamemnon revealed that while nano-formulation enhances the virulence of fungus spores against corn pests, it also results in environmental factors including sunlight, $\mathrm{C}: \mathrm{N}$ ratio and ultra violet light being less detrimental to fungal spores $[77,78]$. Although there have been many studies in this area, further, formulation-related research areas may open to address other environmental factors the fungal product may face during its use in protected growing conditions or out in the field. 


\section{Laboratory Studies and Caged Field Trials Testing the Efficacy of M. flavoviride}

Several methods have been used to test the efficacy of $M$. flavoviride in bioassays against target organisms under laboratory and semi-open field conditions (using cages as meta-environments). Conidial suspension by spinning disc applicator was used against Homoptera: Delphacidae [79], fungal inoculum applied directly to the body was used against Orthoptera: Acrididae [80] while immersion to conidial suspension and inoculated near the mouthpart of the body were tested on Coleoptera: Curculionidae and Orthoptera: Acrididae and Phalacridae [81,82]. A significantly positive effect was detected when spores were applied as oil or water-based suspensions, but conidial dosage and relative humidity increased the mortality of target pests in all cases. Caged field studies revealed that $11 \%$ of tested bees (Hymenoptera: Apidae) became infected, while the IMI 330189 formulated M. flavoviride spores showed moderate virulence to termites and none at all to several species of beetles, to weevils, coreid bugs, ants and cockroaches [83]. Several studies tested the effect of $M$. flavoviride on Orthoptera: Acrididae when the targets were sprayed with blastophore suspension [34], inoculated with conidial suspension [84], fed by baits inoculated with fungus [85], topically administered with the fungus [86-88] and in some studies, the consumption of leaves treated with fungal suspension by target species was observed $[70,85,89]$. Some of these studies recorded a remarkable adverse effect of the fungus on the food intake of infected nymphs and adults of Orthoptera: Acrididae $[85,89]$. Later studies also detected a similar effect on other target pests including Lepidoptera: Noctuidae, Pyralidae and Crambidae; when nano-formulated fungus spores of $M$. flavoviride were offered ad libitum $[77,78]$ and against Coleoptera: Tenebrionidae; and when the administration of different conidial concentrations of M. flavoviride reduced the infection of wheat by Fusarium culmorum [90]. The importance of bioassays is also reflected in the number and stable frequency of bioassay studies over the decades (Table 2). As pest control faces new challenges with the introduction and spread of arthropod species into regions where they were previously unknown, M. flavoviride may offer a solution and screening for its efficacy against invasive arthropods is advisable.

\section{Efficacy of M. flavoviride under Greenhouse and Open Field Conditions}

Greenhouse and open field studies take the promising candidate, a fungal strain or isolate a step closer to the conditions of actual sustainable crop protection. The outcome of studies testing the pathogenicity of M. flavoviride in a near-realistic environment may redefine the limitations of a fungus-based product. The first and effective open field trials using $M$. flavoviride were conducted by Lomer et al. [50,51], when the effect of the fungus on Orthoptera: Pyrgomorphidae was tested in a mixed-vegetable field. Later studies also demonstrated that $M$. flavoviride can be an effective biological control agent against several pests including Orthoptera: Acrididae and Gryllidae in vegetable crops $[36,51,91]$ and Lepidoptera: Noctuidae, Pyralidae and Crambidae in corn $[77,78]$ and Lepidoptera: Gelechiidae in potato under both field and greenhouse conditions [77]. Some of these studies used nano-formulated spores, a formulation type that proved to be one of the most effective in the case of $M$. flavoviride. Although the effectiveness of $M$. flavoviride have been tested and demonstrated under field conditions, so far only a few studies (incl. [36]) added extra method variables (spray bands, aerial and mounted spray) that were proven effective against Orthopteran species.

\section{Studies on the Compatibility of Management Types and Agricultural Substances on M. flavoviride}

A fungus-based product in actual use has to overcome challenges posed by variable in the agricultural environment including the use of chemical and organic pesticides and fertilizers, both chemical and organic. The amount and type of tillage may also have an influence on the performance of an otherwise promising strain or isolate. 
The number of studies testing the antagonistic effect of certain agricultural compounds on M. flavoviride is surprisingly low. It appears that although $M$. flavoviride is available as a ready-to-use biopesticide, there has not been any detailed study to examine the influence of soil type, tillage, or lack of tillage, mulching, irrigation method, or the co-presence of chemical or organic substances, on the performance of $M$. flavoviride.

In laboratories, the growth of $M$. flavoviride was restricted by fungicides in two studies: the first had benomyl [53], the second had carbendazim, a mixture of trifloxystrobin and tebuconazole [92]. The deleterious effect of pesticides on fungal efficacy was also confirmed in the laboratory, when fungal entomopathogens (including Metarhizium sp.) were isolated with the Galleria-method from barley fields that were receiving various pesticides (two fungicides, two insecticides, an herbicide) for an extended period of time [53]. The authors argue that the effect of pesticides on fungal performance may vary greatly as there are a multitude of biotic and abiotic factors in the environment to influence the viability, abundance and efficacy of entomopathogenic fungi.

The effect of agricultural management on the performance of $M$. flavoviride awaits further studies, but meaningful differences were found between the species richness of fungal entomopathogens in organic and conventional fields [93]: when conventional and organic fertilizers (N, P, K; pig slurry, green manure) were tested under field conditions, the positive effect of the organic amendments was proven even when they were involved in a small portion of the total amount of nutrients supplied; thereby confirming that fertilizers used in integrated management may have some beneficial effect on M. flavoviride [94,95].

\section{Conclusions}

Our aims were to revise the scientific knowledge of $M$. flavoviride and to provide a comprehensive review on its production, formulation, use and effectiveness against arthropod pests (Table 2). It appears that not every member of the Metarhizium genus received equal shares of scientific attention. We conclude that more studies are needed to investigate the rhizosphere and document the behavior of M. flavoviride and give account of its potential endophytic nature. We are also yet to discover the extent of the plant supportive and soil enhancing effects of $M$. flavoviride. We suggest that more effort put into exploring a variety of microenvironments in search of M. flavoviride, and similarly, more effort put into understanding the circumstances under which the species is able to perform well. To understand the limits of fungal performance, we are still in need of defining and tailoring fermentation and formulation protocols to specific application conditions. An array of environmental factors needs exploration in relation to the performance of $M$. flavoviride. It can also be suggested, that more studies are needed with an increased range and type of test variable to help $M$. flavoviride strains and isolates become safe and reliable biocontrol agents and commercial products. We envisage studies exploring the compatibility of $M$. flavoviride as a fungal entomopathogen with elements of agricultural management, tillage, agrochemicals, and herbal products. Finally, a series of intricate tests are advised to investigate the effects of $M$. flavoviride as an effective control agent in sustainable management and its effects on non-target organisms, and also there is a need to explore the potential risk the species may pose to human health. 
Table 2. The effect of fermentation, formulation and the efficacy of Metarhizium flavoviride sensu lato under greenhouse and open field conditions. We selected studies that provide suggestions for the application of M. flavoviride s. lato against arthropod pests. Note that before the general spread of rDNA sequence data-based examination (i.e., before 2000) species identification used to rely on conidial shape and size, so earlier publications using acridid pests as target species may either actually have M. flavoviride s. lato or M. acridum as their fungal agent. Isolate FI985 for example should be named M. acridum.

\begin{tabular}{|c|c|c|c|c|c|}
\hline \multirow[b]{2}{*}{ Year } & \multicolumn{5}{|c|}{ Effect of Fermentation on the Performance of Metarhizium flavoviride } \\
\hline & Culture Variable & Other Conditions & Measured Outcome & References & Observations \\
\hline 1993 & Medium content & na. & Conidial production & $\begin{array}{c}\text { Jenkins and Prior } 1993 \\
\text { [65] }\end{array}$ & $\begin{array}{l}\text { First record of } M . \\
\text { flavoviride in } \\
\text { submerged culture }\end{array}$ \\
\hline 1993 & Medium content & Conidial concentration & $\begin{array}{l}\text { Mortality of targets and secondary } \\
\text { sporulation }\end{array}$ & Lomer et al., 1993 [50] & \\
\hline 1994 & $\begin{array}{l}\text { Medium content, } \\
\text { incubation temperature }\end{array}$ & $\begin{array}{l}\text { Length of storage, high } \\
\text { temperature after storage }\end{array}$ & Germination rate & $\begin{array}{l}\text { McClatchie et al., } 1994 \\
\text { [66] }\end{array}$ & \\
\hline 1996 & Age of culture & $\begin{array}{l}\text { Stored as powder or } \\
\text { oil-formation, silica gel }\end{array}$ & Viability, moisture content & Moore et al., 1996 [67] & \\
\hline 1997 & $\begin{array}{l}\text { Addition of fatty acids of } \\
\text { various chain lengths }\end{array}$ & $\begin{array}{l}\text { Acids added, time, previous } \\
\text { storage; inhibitor and promoter }\end{array}$ & Germination percentage & $\begin{array}{l}\text { Barnes and Moore } 1997 \\
\text { [68] }\end{array}$ & \\
\hline 1997 & $\begin{array}{c}\text { C:N ratio, age of culture } \\
\text { (time passed after } \\
\text { inoculation) }\end{array}$ & $\begin{array}{l}\text { Air-drying, temperature and } \\
\text { method (dry powder or in oil) }\end{array}$ & Conidial viability (germination) & $\begin{array}{l}\text { Moore and Higgins } \\
1997 \text { [69] }\end{array}$ & \\
\hline 2000 & $\begin{array}{l}\text { Length of incubation after } \\
\text { inoculation }\end{array}$ & Speed of drying & Germination rate & Hong et al. 2000 [96] & \\
\hline 2001 & Growing media & Lighting regime & Diameter of colonies, number of conidia & Onofre et al. 2001 [97] & \\
\hline 2001 & Growing media & na. & $\begin{array}{l}\text { Conidial production, morphological } \\
\text { features, fungal pathogenicity }\end{array}$ & Fargues et al. 2002 [70] & \\
\hline 2005 & $\begin{array}{c}\text { N sources in the medium; } \\
\text { C:N ratio; amount of } \\
\text { oxygen }\end{array}$ & $\mathrm{pH}$ regulation & $\begin{array}{l}\text { Conidial growth, production of conidia } \\
\text { and blastospores }\end{array}$ & Issaly et al. 2005 [71] & $\begin{array}{c}\text { First record of culture } \\
\text { parameters on } \\
\text { blastospores in } \\
\text { submerged culture }\end{array}$ \\
\hline
\end{tabular}


Table 2. Cont.

\begin{tabular}{|c|c|c|c|c|}
\hline & \multicolumn{4}{|c|}{ Effect of formulation on the performance of Metarhizium flavoviride } \\
\hline & Experimental condition or variable & Type of formulation & Reference & Note \\
\hline 1993 & $\begin{array}{l}\text { Wavelength of solar radiation, age of } \\
\text { cultures, oils added, sunscreens }\end{array}$ & Sunscreen compounds dissolved in oils & Moore et al., 1993 [73] & Simulated UV-exposure in a laboratory \\
\hline 1993 & $\begin{array}{l}\text { Formulation, relative humidity, conidial } \\
\text { concentrations }\end{array}$ & Oil- or water-based formulation & Bateman et al., 1993 [74] & $\begin{array}{l}\text { Efficacy against target organism was } \\
\text { tested }\end{array}$ \\
\hline 1993 & $\begin{array}{l}\text { Length and temperature of storage, oils, } \\
\text { drying }\end{array}$ & $\begin{array}{l}\text { Oils of mineral, vegetable and animal } \\
\text { origin, molasses }\end{array}$ & Stathers et al., 1993 [98] & A storage experiment \\
\hline 1994 & Formulation type & Oil-based and water-based formulations & Ball et al., 1994 [75] & $\begin{array}{c}\text { Formulation types and dosages on } \\
\text { targets and non-targets }\end{array}$ \\
\hline 1994 & Length of sunlight, time & Sunscreens & Hunt et al., 1994 [76] & \\
\hline 1994 & Oil type, silica gel, temperature, time & Vegetable oils mixed with mineral oils & McClatchie et al., 1994 [66] & \\
\hline 1995 & $\begin{array}{l}\text { Storage time and temperature, addition of } \\
\text { antioxidants, silica gel }\end{array}$ & Vegetable or mineral oils & Moore et al., 1995 [86] & Efficacy against target organism \\
\hline 1995 & Oil type and degree of refinement, time & Vegetable and mineral oils & Prior et al., 1995 [84] & $\begin{array}{l}\text { Stand-alone toxicity of oils that are } \\
\text { optional in formulations }\end{array}$ \\
\hline 1996 & $\begin{array}{l}\text { Oils, silica gel; storage with or without } \\
\text { formulation; storage time and temperature }\end{array}$ & Addition of oils to conidia & Moore et al., 1996 [67] & \\
\hline 1996 & Type and freshness of bait & Ingredients within bait & Caudwell and Gatehouse 1996 [85] & \\
\hline 1996 & $\begin{array}{l}\text { Formulation type, temperatures, incubation } \\
\text { temperature, storage time }\end{array}$ & Oil and dry formulation, silica gel & Morley-Davies et al., 1996 [99] & \\
\hline 1997 & Clay types, storage temperature, an oil mix & $\begin{array}{l}\text { Minerals to conidial suspension, a mineral } \\
\text { oil-mixture }\end{array}$ & Moore and Higgins 1997 [69] & \\
\hline 1997 & $\begin{array}{l}\text { Types of clay, storage temperature, addition } \\
\text { of an oil mix }\end{array}$ & $\begin{array}{l}\text { Minerals to conidial suspension, a mineral } \\
\text { oil-mixture }\end{array}$ & Moore and Higgins 1997 [69] & Types of clays, surface areas \\
\hline 1997 & $\begin{array}{l}\text { Temperature, inoculation method, spore } \\
\text { carrier, relative humidity }\end{array}$ & Oil suspensions and aqueous suspension & Ouedraogo et al., 1997 [88] & $\begin{array}{l}\text { Efficacy against target organisms. } \\
\text { Carrier type and inoculation method }\end{array}$ \\
\hline 1998 & $\begin{array}{l}\text { Sunscreen oil, time after treatment, time of } \\
\text { application }\end{array}$ & Oil suspensions & Shah et al., 1998 [100] & $\begin{array}{c}\text { Caged field trial. Efficacy against target } \\
\text { organisms }\end{array}$ \\
\hline 2015 & Nano technique, conidial concentrations & Nano-formulated fungus & Sabbour $2015[77,78]$ & Efficacy against target organisms \\
\hline 2015 & Solar radiation, time, oils and sunscreens. & Oil suspension & Fernandes et al. 2015 [101] & UV-tolerance and the country of origin \\
\hline
\end{tabular}


Table 2. Cont

\begin{tabular}{|c|c|c|c|c|c|}
\hline & \multicolumn{5}{|c|}{ Laboratory studies and caged field trials testing the effect of $M$. flavoviride } \\
\hline & Conditions & Targeted Order: Family & Method & Reference & Note \\
\hline 1983 & Temperature, conidial concentrations & Coleoptera: Curculionidae & $\begin{array}{l}\text { Spraying with a spray tower } \\
\text { apparatus }\end{array}$ & Soares et al., 1983 [102] & \\
\hline 1987 & None & Homoptera: Delphacidae & $\begin{array}{l}\text { Conidial suspension by spinning } \\
\text { disc applicator }\end{array}$ & Aguda et al., 1987 [79] & $\begin{array}{l}\text { Caged field trial. } M . \\
\text { flavoviride var. minus }\end{array}$ \\
\hline 1992 & Conidial concentration & Orthoptera: Acrididae & $\begin{array}{l}\text { Fungal inoculum applied to the } \\
\text { body of targets }\end{array}$ & Moore et al., 1992 [80] & \\
\hline 1993 & $\begin{array}{l}\text { Formulation type, conidial } \\
\text { concentration, relative humidity }\end{array}$ & Orthoptera: Acrididae & Topical administration & $\begin{array}{c}\text { Bateman et al., 1993; Lomer et al., } \\
1997[51,74]\end{array}$ & \\
\hline 1993 & Various isolates & Coleoptera: Curculionidae & Immersion to conidial suspension & Moorhouse et al., 1993 [81] & M. flavoviride var. minus \\
\hline 1993 & Conidial concentrations & $\begin{array}{l}\text { Orthoptera: Acrididae and } \\
\text { Phalacridae }\end{array}$ & $\begin{array}{l}\text { Inoculated at the mouthpart of the } \\
\text { body }\end{array}$ & Milner and Prior 1994 [82] & \\
\hline 1994 & None & Orthoptera: Acrididae & $\begin{array}{l}\text { Conidial suspension applied } \\
\text { topically }\end{array}$ & Seyoum et al., 1994 [83] & $\begin{array}{l}\text { Flight and feeding } \\
\text { behaviour }\end{array}$ \\
\hline 1994 & Temperature & Orthoptera: Acrididae & $\begin{array}{l}\text { Spraying with blastophore } \\
\text { suspension }\end{array}$ & Welling et al., 1994 [34] & \\
\hline 1995 & $\begin{array}{l}\text { Age and sex of targets, fungal } \\
\text { concentration and site of inoculation, } \\
\text { various formulation oils }\end{array}$ & Orthoptera: Acrididae & $\begin{array}{l}\text { Inoculation with conidial } \\
\text { suspension }\end{array}$ & Prior et al., 1995 [84] & \\
\hline 1995 & $\begin{array}{l}\text { Formulation oils, presence of an } \\
\text { antioxidant, humidity of product, } \\
\text { storage conditions }\end{array}$ & Orthoptera: Acrididae & Topical administration & Moore et al., 1995 [86] & \\
\hline 1996 & $\begin{array}{c}\text { Conidial concentrations, components of } \\
\text { bait }\end{array}$ & Orthoptera: Acrididae & Feeding bait inoculated with fungus & Caudwell and Gatehouse 1996 [85] & \\
\hline 1996 & Freshness of bait & Orthoptera: Acrididae & Baited feeding & Caudwell and Gatehouse 1996 [85] & Caged field study \\
\hline 1996 & Conidial concentrations & Orthoptera: Acrididae & Topical administration & Milner et al., 1996 [87] & \\
\hline 1997 & $\begin{array}{l}\text { Droplet size, per hectare volume, type of } \\
\text { enclosure }\end{array}$ & Orthoptera: Acrididae & Aerial spray & Price et al., 1997 [103] & $\begin{array}{l}\text { Caged field and enclosed } \\
\text { field study }\end{array}$ \\
\hline 1997 & Fungal isolates, temperature & Orthoptera: Acrididae & Inoculated at body parts & Milner 1997 [36] & \\
\hline 1997 & $\begin{array}{l}\text { Basking, temperature, combination with } \\
\text { another fungus. }\end{array}$ & Orthoptera: Acrididae & Inoculated feed & Inglis et al., 1997 [104] & \\
\hline
\end{tabular}


Table 2. Cont

\begin{tabular}{|c|c|c|c|c|c|}
\hline \multicolumn{6}{|c|}{ Laboratory studies and caged field trials testing the effect of $M$. flavoviride } \\
\hline & Conditions & Targeted Order: Family & Method & Reference & Note \\
\hline 1997 & $\begin{array}{l}\text { Method of fungal administration, } \\
\text { temperature and humidity }\end{array}$ & Orthoptera: Acrididae & Topical inoculation or spray & Ouedraogo et al., 1997 [88] & \\
\hline 1997 & $\begin{array}{l}\text { Conidial concentration, method of } \\
\text { fungal administration }\end{array}$ & $\begin{array}{l}\text { Coleoptera: Coccinellidae } \\
\text { and Tenebrionidae, } \\
\text { Neuroptera: } \\
\text { Myrmeleontidae, Araneae: } \\
\text { Philodromidae, Orthoptera: } \\
\text { Acrididae }\end{array}$ & $\begin{array}{l}\text { Exposure to leaves treated with } \\
\text { fungal suspension, fungus-treated } \\
\text { feed, topical administration }\end{array}$ & Peveling and Demba 1997 [89] & $\begin{array}{l}\text { Study aimed at } \\
\text { non-target arthropods. }\end{array}$ \\
\hline 1997 & Temperature and conidial concentration & $\begin{array}{c}\text { Orthoptera: } \\
\text { Pyrgomorphidae }\end{array}$ & Topical administration & Thomas and Jenkins 1997 [105] & \\
\hline 1997 & Spore concentrations & $\begin{array}{c}\text { Orthoptera: } \\
\text { Pyrgomorphidae }\end{array}$ & Topical administration & Thomas et al., 1997 [106] & Caged field study \\
\hline 1997 & $\begin{array}{l}\text { Temperature, Beauveria bassiana } \\
\text { (Balsamo-Crivelli) Vuillemin } \\
\text { (Hypocreales: Cordycipitaceae) }\end{array}$ & Orthoptera: Acrididae & Feeding inoculated leaves & Inglis et al., 1997 [104] & \\
\hline 1997 & $\begin{array}{l}\text { Moisture content of dehydrated conidia, } \\
\text { rehydration time }\end{array}$ & Orthoptera: Acrididae & $\begin{array}{l}\text { spray with a medium-droplet } \\
\text { applicator }\end{array}$ & Moore et al., 1997 [107] & Caged field study \\
\hline 1998 & $\begin{array}{l}\text { Temperature and relative humidity, } \\
\text { various life stages of pest }\end{array}$ & Orthoptera: Acrididae & Ultra-low volume-spray & Sieglaff et al., 1998 [108] & $\begin{array}{l}\text { Caged greenhouse, a } \\
\text { follow-up study }\end{array}$ \\
\hline 1998 & $\begin{array}{l}\text { Conidial concentrations, age of fungal } \\
\text { cultures }\end{array}$ & Orthoptera: Acrididae & Spray or topical administration & Sieglaff et al., 1998 [108] & This was the initial study \\
\hline 1998 & Time after treatment, sunscreens & Orthoptera: Acrididae & Spray & Shah et al., 1998 [100] & Caged field study \\
\hline 1999 & $\begin{array}{l}\text { Conidial concentrations, addition of } B \text {. } \\
\text { bassiana, temperature regimes }\end{array}$ & Orthoptera: Acrididae & Inoculated feed & Inglis et al., 1999 [109] & \\
\hline 2001 & Components of medium & Orthoptera: Acrididae & Leaves treated with fungus & Fargues et al. 2002 [70] & \\
\hline 2008 & Isolates, conidial concentrations & Homoptera: Delphacidae & Spore suspension spray & Jin et al. 2008 [110] & $\begin{array}{l}\text { With } M \text {. flavoviride var. } \\
\text { minus }\end{array}$ \\
\hline 2011 & None & Hemiptera: Reduviidae & Conidial spray & Rocha and Luz 2011 [111] & $\begin{array}{l}\text { The first report of } M \text {. } \\
\text { flavoviride var. pemphigi } \\
\text { against Triatoma infestans }\end{array}$ \\
\hline
\end{tabular}


Table 2. Cont

\begin{tabular}{|c|c|c|c|c|c|}
\hline & \multicolumn{5}{|c|}{ Laboratory studies and caged field trials testing the effect of $M$. flavoviride } \\
\hline & Conditions & Targeted Order: Family & Method & Reference & Note \\
\hline 2011 & Conidial concentrations & Lepidoptera: Noctuidae & Surface contamination & Belen et al. 2011 [57] & \\
\hline 2012 & Isolates, life stage of pests & Homoptera: Delphacidae & Fungal suspension spray & Li et al. 2012 [112] & \\
\hline 2014 & $\begin{array}{c}\text { Presence of a major accumulation } \\
\text { pheromone }\end{array}$ & Orthoptera: Acrididae & Topical application & Gorashi 2014 [113] & $\begin{array}{l}\text { Feeding and movements } \\
\text { were recorded }\end{array}$ \\
\hline 2015 & Conidial concentrations & $\begin{array}{l}\text { Lepidoptera: Noctuidae, } \\
\text { Pyralidae and Crambidae }\end{array}$ & na. & Sabbour 2015 [78] & Nano-formulated fungus \\
\hline 2015 & None & Hemiptera: Aphididae & Hand spray or tower spray & Lee et al. 2015 [114] & \\
\hline 2015 & $\begin{array}{l}\text { Other fungal entomopathogens, method } \\
\text { of infection, conidial concentration }\end{array}$ & Coleoptera: Tenebrionidae & $\begin{array}{l}\text { Seed treatment, inoculation, } \\
\text { fungus-treated feed }\end{array}$ & Rangel et al. 2015 [90] & $\begin{array}{l}\text { Fungal combinations } \\
\text { tested against Fusarium } \\
\text { culmorum }\end{array}$ \\
\hline 2015 & Conidial concentrations & $\begin{array}{l}\text { Lepidoptera: Noctuidae, } \\
\text { Pyralidae and Crambidae }\end{array}$ & Fungus-treated leaves & Sabbour 2015 [77] & \\
\hline 2015 & Conidial concentrations & Lepidoptera: Gelechiidae & Leaves treated with fungus & Sabbour 2015 [77] & Nano-formulated fungus \\
\hline 2015 & Different strains & $\begin{array}{c}\text { Lepidoptera: Pyralidae, } \\
\text { Coleoptera: } \\
\text { Chrysomelidae, } \\
\text { Tenebrionidae and } \\
\text { Curculionidae }\end{array}$ & Topical administration & Kocaçevik et al. 2015 [62] & $\begin{array}{c}\text { The fungal isolate used } \\
\text { was initially found on } \\
\text { larvae of Amphimallon } \\
\text { solstitiale }\end{array}$ \\
\hline 2017 & $\begin{array}{l}\text { Rice variety and temperature, a } \\
\text { symbiotic bacterium }\end{array}$ & Homoptera: Delphacidae & Exposure to fungal suspension & Huanhuan et al. 2017 [115] & \\
\hline 2017 & $\begin{array}{l}\text { Combinations of temperature and } \\
\text { relative humidity }\end{array}$ & Coleoptera: Chrysomelidae & Conidial suspension & Kryukov et al. 2017 [116] & M. pemphigi \\
\hline 2017 & $\begin{array}{c}\text { Conidial concentrations, spray cover, life } \\
\text { stages }\end{array}$ & $\begin{array}{l}\text { Trombidiformes: } \\
\text { Tetranychidae }\end{array}$ & Spraying spore suspension & Dogan et al. 2017 [117] & $\begin{array}{l}\text { Petri dish and pot } \\
\text { experiments }\end{array}$ \\
\hline 2018 & None & $\begin{array}{l}\text { Hemiptera: Alydidae, } \\
\text { Lepidoptera: Plutellidae } \\
\text { and Coleoptera: } \\
\text { Tenebrionidae }\end{array}$ & Fungal cultures & Kim et al. 2018 [8] & $\begin{array}{l}\text { Fungal isolates from a } \\
\text { fungal library }\end{array}$ \\
\hline
\end{tabular}


Table 2. Cont.

\begin{tabular}{|c|c|c|c|c|c|c|}
\hline \multicolumn{7}{|c|}{ Effect of $M$. flavoviride under greenhouse and open field conditions } \\
\hline & Location & Target & Crop & Method & Source & Note \\
\hline 1993 & Field & $\begin{array}{l}\text { Orthoptera: } \\
\text { Pyrgomorphidae }\end{array}$ & $\begin{array}{l}\text { none or mixed } \\
\text { vegetables }\end{array}$ & Spray & Lomer et al., 1993, $1997[50,51]$ & $\begin{array}{l}\text { The first outdoor trials } \\
\text { with M. flavoviride }\end{array}$ \\
\hline 1995 & Field & $\begin{array}{l}\text { Orthoptera: } \\
\text { Pyrgomorphidae }\end{array}$ & $\begin{array}{l}\text { cassava, shrub, chili } \\
\text { and other vegetables }\end{array}$ & $\begin{array}{l}\text { Spinning } \\
\text { disc } \\
\text { sprayer }\end{array}$ & \multicolumn{2}{|l|}{$\begin{array}{l}\text { Douro-Kpindou et al., 1995; Lomer } \\
\text { et al., } 1997[51,118]\end{array}$} \\
\hline 1997 & Field & $\begin{array}{l}\text { Orthoptera: Acrididae and } \\
\text { Gryllidae }\end{array}$ & none & $\begin{array}{c}\text { Spray } \\
\text { bands, } \\
\text { aerial and } \\
\text { mounted } \\
\text { spray }\end{array}$ & \multicolumn{2}{|l|}{$\begin{array}{l}\text { Lomer et al., 1997; Milner } 1997 \\
\text { [36,51] }\end{array}$} \\
\hline 1997 & Field & Orthoptera: Acrididae & none & $\begin{array}{l}\text { Hand-held } \\
\text { sprayer }\end{array}$ & \multicolumn{2}{|l|}{$\begin{array}{l}\text { Langewald et al., 1997; Lomer et } \\
\text { al., } 1997[51,91]\end{array}$} \\
\hline 1997 & Field & Orthoptera & various & Various & Lomer et al., 1997 [51] & $\begin{array}{l}\text { A review including caged } \\
\text { field studies and } \\
\text { formulation studies }\end{array}$ \\
\hline 2015 & Field & Lepidoptera: Crambidae & corn & Spray & Sabbour 2015 [77] & \\
\hline 2015 & Field & $\begin{array}{l}\text { Lepidoptera: Noctuidae, } \\
\text { Pyralidae and Crambidae }\end{array}$ & corn & Spray & Sabbour 2015 [78] & Nano-formulated fungus \\
\hline \multirow[t]{3}{*}{2015} & Field and greenhouse & Lepidoptera: Gelechiidae & potato & Spray & Sabbour 2015 [77] & Nano-formulated fungus \\
\hline & \multicolumn{6}{|c|}{ Studies on the compatibility of management types and agricultural substances on $M$. flavoviride } \\
\hline & Variable & Type of variable & \multicolumn{2}{|l|}{ Source } & \multicolumn{2}{|l|}{ Note } \\
\hline 1997 & $\begin{array}{l}\text { Chemical treatments to soil before } \\
\text { isolation of fungus, temperature }\end{array}$ & $\begin{array}{l}\text { Herbicide, fungicide and } \\
\text { insecticide }\end{array}$ & \multicolumn{2}{|c|}{ Mietkiewski et al., 1997 [53] } & \multicolumn{2}{|c|}{ Laboratory test } \\
\hline 2011 & Concentration of chemical & Fungicide & \multicolumn{2}{|c|}{ Damin et al. 2011 [92] } & \multicolumn{2}{|c|}{ Laboratory test } \\
\hline 2011 & $\begin{array}{l}\text { Fertilizer in double and single amount, } \\
\text { organic manure }\end{array}$ & $\mathrm{N}, \mathrm{P}, \mathrm{K}$, and organic manure & \multicolumn{2}{|c|}{ Jarmul-Pietraszczyk et al. 2011 [94] } & \multicolumn{2}{|c|}{ Field study } \\
\hline 2011 & $\begin{array}{l}\text { Conventional and organic fertilization, } \\
\text { presence of plants }\end{array}$ & $\begin{array}{l}\mathrm{N}, \mathrm{P}, \mathrm{K} \text {; pig slurry, green } \\
\text { manure }\end{array}$ & \multicolumn{2}{|c|}{ Meyling et al. 2011 [95] } & \multicolumn{2}{|c|}{ Field study } \\
\hline
\end{tabular}


Table 2. Cont

\begin{tabular}{|c|c|c|c|c|}
\hline & \multicolumn{4}{|c|}{ Studies on the compatibility of management types and agricultural substances on $M$. flavoviride } \\
\hline & Variable & Type of variable & Source & Note \\
\hline \multirow[t]{3}{*}{2016} & Management type & Organic, conventional & $\begin{array}{l}\text { Sammaritano et al. 2016; de Castro } \\
2016[93,119]\end{array}$ & $\begin{array}{l}\text { Collection of fungal entomopathogens directly from the soil [93] } \\
\text { or from soil samples for identification and further use }\end{array}$ \\
\hline & \multicolumn{4}{|c|}{ Studies on the effect of M. flavoviride on non-target species } \\
\hline & Non-target organism & Conditions of application & Source & Note \\
\hline 1994 & Hymenoptera: Apidae & $\begin{array}{l}\text { Oil and water-based } \\
\text { formulations, conidial } \\
\text { dosage, spray }\end{array}$ & Ball et al. [75], & Caged study \\
\hline 1997 & $\begin{array}{l}\text { Coleoptera: Coccinellidae and } \\
\text { Tenebrionidae, Neuroptera: } \\
\text { Myrmeleontidae, Araneae: } \\
\text { Philodromidae }\end{array}$ & $\begin{array}{l}\text { Exposure to leaves treated } \\
\text { with fungal suspension, } \\
\text { fungus-treated feed, topical } \\
\text { administration }\end{array}$ & Peveling et al. [89] & $\begin{array}{l}\text { Conidial concentration, method of fungal administration were } \\
\text { also studied }\end{array}$ \\
\hline 1999 & Galliformes: Phasianidae & $\begin{array}{l}\text { ingestion of spore-coated } \\
\text { feed, ingestion of infected } \\
\text { insects }\end{array}$ & Smits et al. [120] & \\
\hline
\end{tabular}


Author Contributions: Conceptualization, F.T.B., F.T., J.B. and A.B.; methodology, F.T.B., R.P., B.P.-C., A.G. and F.T.; validation, F.T.B., F.T. and A.B.; data curation, F.T.B., F.T., J.B. and A.B.; Writing-Original draft preparation, F.T.B., F.T., J.B. and A.B.; Writing-Review and editing, F.T.B., F.T., J.B. and A.B.; visualization, F.T.B., R.P., B.P.-C., A.G. and F.T.; supervision, F.T.B., F.T., J.B. and A.B; project administration, J.B., B.P.-C. and A.G; funding acquisition, J.B. and A.B.

Funding: This research was funded by the Institute of Research Programs of the Sapientia Hungarian University of Transylvania grant No. 21/2/12.06.2019. The APC was founded by the Sapientia Hungarian University of Transylvania. For Szent István University co-authors supports were made by the project of the National Research, Development and Innovation Office (KFI_16-1-2017-0272) and by the Higher Education Institutional Excellence Program (1783-3/2018/FEKUTSTRAT) awarded by the Ministry of Human Capacities within the framework of plant breeding and plant protection researches of Szent István University.

Acknowledgments: The authors would like to express their special thanks to Erik Czinege (Kwizda Agro Hungary Kft.), Gyula Bohár (Biovéd 2005 Kft.) and György Turóczi (Szent István University) for the original idea to expand our knowledge of Metarhizium flavoviride, a potential new candidate for biopesticide development.

Conflicts of Interest: The authors of this article have no financial or other conflict of interest to declare.

\section{References}

1. Mascarin, G.M.; Lopes, R.B.; Delalibera, Í.; Fernandes, É.K.K.; Luz, C.; Faria, M. Current status and perspectives of fungal entomopathogens used for microbial control of arthropod pests in Brazil. J. Invertebr. Pathol. 2018, 165, 46-53. [CrossRef] [PubMed]

2. Razinger, J.; Schroers, H.J.; Urek, G. Virulence of Metarhizium brunneum to field collected Agriotes spp. wireworms. J. Agric. Sci. Technol. 2018, 20, 309-320.

3. Eckard, S.; Ansari, M.A.; Bacher, S.; Butt, T.M.; Enkerli, J.; Grabenweger, G. Virulence of in vivo and in vitro produced conidia of Metarhizium brunneum strains for control of wireworms. Crop Prot. 2014, 64, 137-142. [CrossRef]

4. Ansari, M.A.; Butt, T.M. Evaluation of entomopathogenic fungi and a nematode against the soil-dwelling stages of the crane fly Tipula paludosa. Pest Manag. Sci. 2012, 68, 1337-1344. [CrossRef]

5. Kergunteuil, A.; Bakhtiari, M.; Formenti, L.; Xiao, Z.; Defossez, E.; Rasmann, S. Biological control beneath the feet: A review of crop protection against insect root herbivores. Insects 2016, 7, 70. [CrossRef]

6. Herbst, M.; Razinger, J.; Ugrinović, K.; Škof, M.; Schroers, H.-J.; Hommes, M.; Poehling, H.-M. Evaluation of low risk methods for managing Delia radicum, cabbage root fly, in broccoli production. Crop Prot. 2017, 96, 273-280. [CrossRef]

7. Fronza, E.; Specht, A.; Heinzen, H.; de Barros, N.M. Metarhizium (Nomuraea) rileyi as biological control agent. Biocontrol Sci. Technol. 2017, 27, 1243-1264. [CrossRef]

8. Kim, J.C.; Lee, M.R.; Kim, S.; Lee, S.J.; Park, S.E.; Nai, Y.-S.; Lee, G.S.; Shin, T.Y.; Kim, J.S. Tenebrio molitor-mediated entomopathogenic fungal library construction for pest management. J. Asia Pac. Entomol. 2018, 21, 196-204. [CrossRef]

9. Skinner, M.; Parker, B.L.; Kim, J.S. Role of entomopathogenic fungi in integrated pest management. In Integrated Pest Management; Abrol, D.P., Ed.; Academic Press: San Diego, CA, USA, 2014; pp. 169-191. ISBN 978-0-12-398529-3.

10. Milner, R.J. Current status of Metarhizium as a mycoinsecticide in Australia. Biocontrol News Inf. 2000, 21, 47N-50N.

11. Maina, U.M.; Galadima, I.B.; Gambo, F.M.; Zakaria, D. A review on the use of entomopathogenic fungi in the management of insect pests of field crops. J. Entomol. Zool. Stud. 2018, 6, $27-32$.

12. Kepler, R.M.; Humber, R.A.; Bischoff, J.F.; Rehner, S.A. Clarification of generic and species boundaries for Metarhizium and related fungi through multigene phylogenetics. Mycologia 2014, 106, 811-829. [CrossRef] [PubMed]

13. Keyser, C.A.; Jensen, B.; Meyling, N.V. Dual effects of Metarhizium spp. and Clonostachys rosea against an insect and a seed-borne pathogen in wheat. Pest Manag. Sci. 2016, 72, 517-526. [CrossRef] [PubMed]

14. Nishi, O.; Shimizu, S.; Sato, H. Metarhizium bibionidarum and M. purpureogenum: New species from Japan. Mycol. Prog. 2017, 16, 987-998. [CrossRef]

15. African Journal of Agricultural Research. Available online: https://academicjournals.org/journal/AJAR (accessed on 16 July 2019).

16. Fauna Europaea. Available online: https://fauna-eu.org/ (accessed on 16 July 2019). 
17. International Journal of Agriculture Innovations and Research. Available online: https://ijair.org/ (accessed on 16 July 2019).

18. Journal of Entomology and Zoology Studies. Available online: http://www.entomoljournal.com/ (accessed on 16 July 2019).

19. MycoBank Database. Available online: http://www.mycobank.org/ (accessed on 16 July 2019).

20. PubMed-NCBI. Available online: https://www.ncbi.nlm.nih.gov/pubmed/ (accessed on 16 July 2019).

21. ResearchGate. Available online: https://www.researchgate.net/ (accessed on 16 July 2019).

22. ScienceDirect. Available online: https://www.sciencedirect.com/ (accessed on 16 July 2019).

23. Scientific Electronic Library Online. Available online: https://scielo.org/ (accessed on 16 July 2019).

24. Springer. Available online: https://link.springer.com/ (accessed on 16 July 2019).

25. Rehner, S.A.; Kepler, R.M. Species limits, phylogeography and reproductive mode in the Metarhizium anisopliae complex. J. Invertebr. Pathol. 2017, 148, 60-66. [CrossRef]

26. Bidochka, M.J.; Small, C.L. Phylogeography of Metarhizium, an insect pathogenic fungus. In Insect-Fungal Associations: Ecology and Evolution; Oxford University Press: Oxford, UK, 2005; pp. 3-27.

27. Bischoff, J.F.; Rehner, S.A.; Humber, R.A. A multilocus phylogeny of the Metarhizium anisopliae lineage. Mycologia 2009, 101, 512-530. [CrossRef]

28. Brancini, G.T.P.; Tonani, L.; Rangel, D.E.N.; Roberts, D.W.; Braga, G.U.L. Species of the Metarhizium anisopliae complex with diverse ecological niches display different susceptibilities to antifungal agents. Fungal Biol. 2018, 122, 563-569. [CrossRef]

29. Driver, F.; Milner, R.J.; Trueman, J.W.H. A taxonomic revision of Metarhizium based on a phylogenetic analysis of rDNA sequence data. Mycol. Res. 2000, 104, 134-150. [CrossRef]

30. Oliveira, I.V. Entomopathogenic Fungi Associated to Prays oleae: Isolation, Characterization and Selection for Biological Control. Ph.D. Thesis, Universidade do Minho, Braga, Portugal, 2013.

31. Kuznetsov, V.D. The population concept in microbiology. Actinomycetes 1990, 1, 63-66.

32. Lomer, C.J.; Bateman, R.P.; Johnson, D.L.; Langewald, J.; Thomas, M. Biological control of locusts and grasshoppers. Annu. Rev. Entomol. 2001, 46, 667-702. [CrossRef]

33. Bridge, P.D.; Williams, M.A.J.; Prior, C.; Paterson, R.R.M. Morphological, biochemical and molecular characteristics of Metarhizium anisopliae and M. flavoviride. Microbiology 1993, 139, 1163-1169. [CrossRef]

34. Welling, M.; Nachtigall, G.; Zimmermann, G. Metarhizium spp. isolates from madagascar: Morphology and effect of high temperature on growth and infectivity to the migratory locust, Locusta migratoria. Entomophaga 1994, 39, 351-361. [CrossRef]

35. Fernandes, É.K.K.; Keyser, C.A.; Chong, J.P.; Rangel, D.E.N.; Miller, M.P.; Roberts, D.W. Characterization of Metarhizium species and varieties based on molecular analysis, heat tolerance and cold activity. J. Appl. Microbiol. 2010, 108, 115-128. [CrossRef] [PubMed]

36. Milner, R.J. Metarhizium flavoviride (FI985) as a promising mycoinsecticide for Australian acridids. Mem. Entomol. Soc. Can. 1997, 129, 287-300. [CrossRef]

37. Danfa, A.; van der Valk, H.C.H.G. Laboratory testing of Metarhizium spp. and Beauveria bassiana on Sahelian non-target arthropods. Biocontrol Sci. Technol. 1999, 9, 187-198. [CrossRef]

38. van der Valk, H. Review of the Efficacy of Metarhizium anisopliae var. acridum against the Desert Locust; Desert Locust Technical Series AGP. DL/TS/34; Food and Agriculture Organization of the United Nations: Rome, Italy, 2007.

39. Zimmermann, G. Review on safety of the entomopathogenic fungus Metarhizium anisopliae. Biocontrol Sci. Technol. 2007, 17, 879-920. [CrossRef]

40. Bischoff, J.F.; Rehner, S.A.; Humber, R.A. Metarhizium frigidum sp. nov.: A cryptic species of M. anisopliae and a member of the M. flavoviride complex. Mycologia 2006, 98, 737-745. [CrossRef]

41. Pante, E.; Puillandre, N.; Viricel, A.; Arnaud-Haond, S.; Aurelle, D.; Castelin, M.; Chenuil, A.; Destombe, C.; Forcioli, D.; Valero, M.; et al. Species are hypotheses: Avoid connectivity assessments based on pillars of sand. Mol. Ecol. 2015, 24, 525-544. [CrossRef]

42. Greuter, W.; Hawksworth, D.L.; McNeill, J.; Mayo, M.A.; Minelli, A.; Sneath, P.H.A.; Tindall, B.J.; Trehane, P.; Tubbs, P. Draft BioCode (1997): The prospective international rules for the scientific names of organisms. Taxon 1998, 47, 127-150. 
43. Schmelz, R.M.; Rüdiger, M.; Beylich, A.; Boros, G.; Dózsa-Farkas, K.; Graefe, U. How to deal with cryptic species in Enchytraeidae, with recommendations on taxonomical descriptions. Opusc. Zool. Bp. 2017, 48, 45-51. [CrossRef]

44. Hernández-Domínguez, C.; de Cerroblanco-Baxcajay, M.L.; Alvarado-Aragón, L.U.; Hernández-López, G.; Guzmán-Franco, A.W. Comparison of the relative efficacy of an insect baiting method and selective media for diversity studies of Metarhizium species in the soil. Biocontrol Sci. Technol. 2016, 26, 707-717. [CrossRef]

45. Lopes, R.B.; Souza, D.A.; Rocha, L.F.N.; Montalva, C.; Luz, C.; Humber, R.A.; Faria, M. Metarhizium alvesii sp. nov.: A new member of the Metarhizium anisopliae species complex. J. Invertebr. Pathol. 2018, 151, 165-168. [CrossRef] [PubMed]

46. Tulloch, M. The genus Metarhizium. Trans. Br. Mycol. Soc. 1976, 66, 407-411. [CrossRef]

47. Montalva, C.; Collier, K.; Rocha, L.F.N.; Inglis, P.W.; Lopes, R.B.; Luz, C.; Humber, R.A. A natural fungal infection of a sylvatic cockroach with Metarhizium blattodeae sp. nov., a member of the M. flavoviride species complex. Fungal Biol. 2016, 120, 655-665. [CrossRef]

48. Chen, W.H.; Han, Y.F.; Liang, J.D.; Liang, Z.Q.; Jin, D.C. Metarhizium dendrolimatilis, a novel Metarhizium species parasitic on Dendrolimus sp larvae. Mycosphere 2017, 8, 31-37. [CrossRef]

49. Gams, W.; Rozsypal, J. Metarrhizium flavoviride n.sp. isolated from insects and from soil. Acta Bot. Neerl. 1973, 22, 518-521. [CrossRef]

50. Lomer, C.J.; Bateman, R.P.; Godonou, I.; Kpindou, D.; Shah, P.A.; Paraiso, A.; Prior, C. Field infection of Zonocerus variegatus following application of an oil-based formulation of Metarhizium flavoviride conidia. Biocontrol Sci. Technol. 1993, 3, 337-346. [CrossRef]

51. Lomer, C.J.; Prior, C.; Kooyman, C. Development of Metarhizium ssp. for the control of grasshoppers and locusts. Mem. Entomol. Soc. Can. 1997, 129, 265-286. [CrossRef]

52. Velazquez, V.M.H.; Padilla, A.M.B.; Gonzalez, E.G. Detection of Metarhizium flavoviride on Schistocerca piceifrons piceifrons (Orthoptera: Acrididae) in Socorro Island, Archipielago of Revillagigedo, Mexico. VEDALIA 1997, 4, 45-46.

53. Mietkiewski, R.T.; Pell, J.K.; Clark, S.J. Influence of pesticide use on the natural occurrence of entomopathogenic fungi in arable soils in the UK: Field and laboratory comparisons. Biocontrol Sci. Technol. 1997, 7, 565-576. [CrossRef]

54. Shah, P.A.; Gbongboui, C.; Godonou, I.; Hossou, A.; Lomer, C.J. Natural incidence of Metarhizium flavoviride infection in two grasshopper communities in northern Benin. Biocontrol Sci. Technol. 1998, 8, 335-344. [CrossRef]

55. Pokorný, R.; Olejníková, P.; Balog, M.; Zifčák, P.; Hölker, U.; Janssen, M.; Bend, J.; Höfer, M.; Holienčin, R.; Hudecová, D.; et al. Characterization of microorganisms isolated from lignite excavated from the Záhorie coal mine (southwestern Slovakia). Res. Microbiol. 2005, 156, 932-943. [CrossRef] [PubMed]

56. Meyling, N.V.; Eilenberg, J. Occurrence and distribution of soil borne entomopathogenic fungi within a single organic agroecosystem. Agric. Ecosyst. Environ. 2006, 113, 336-341. [CrossRef]

57. Belen, J.M.; Ocampo, V.R.; Caoili, B.L. Pathogenicity and biological characterization of entomopathogenic fungi isolated from corn earworm, Helicoverpa armigera (Hübner) (Lepidoptera: Noctuidae). Philipp. Entomol. 2011, 25, 48-63.

58. Zimmermann, G. The 'Galleria bait method' for detection of entomopathogenic fungi in soil. J. Appl. Entomol. 1986, 102, 213-215. [CrossRef]

59. Fisher, J.J.; Rehner, S.A.; Bruck, D.J. Diversity of rhizosphere associated entomopathogenic fungi of perennial herbs, shrubs and coniferous trees. J. Invertebr. Pathol. 2011, 106, 289-295. [CrossRef] [PubMed]

60. Shin, T.Y.; Lee, W.W.; Ko, S.H.; Choi, J.B.; Bae, S.M.; Choi, J.Y.; Lee, K.S.; Je, Y.H.; Jin, B.R.; Woo, S.D. Distribution and characterisation of entomopathogenic fungi from Korean soils. Biocontrol Sci. Technol. 2013, 23, 288-304. [CrossRef]

61. Steinwender, B.M.; Enkerli, J.; Widmer, F.; Eilenberg, J.; Thorup-Kristensen, K.; Meyling, N.V. Molecular diversity of the entomopathogenic fungal Metarhizium community within an agroecosystem. J. Invertebr. Pathol. 2014, 123, 6-12. [CrossRef]

62. Kocaçevik, S.; Sönmez, E.; Demirbağ, Z.; Demir, I. Isolation, characterization and virulence of highly promising entomopathogenic fungi from Amphimallon solstitiale (Coleoptera: Scarabaeidae). In Proceedings of the Fifth International Entomopathogens and Microbial Control Congress, Ankara, Turkey, 9-11 September 2015. 
63. Piazza, S.D.; Isaia, M.; Vizzini, A.; Badino, G.; Voyron, S.; Zotti, M. First mycological assessment in hydrothermal caves of Monte Kronio (Sicily, southern Italy). Webbia 2017, 72, 277-285. [CrossRef]

64. Steinwender, B.M.; Enkerli, J.; Widmer, F.; Eilenberg, J.; Kristensen, H.L.; Bidochka, M.J.; Meyling, N.V. Root isolations of Metarhizium spp. from crops reflect diversity in the soil and indicate no plant specificity. J. Invertebr. Pathol. 2015, 132, 142-148. [CrossRef]

65. Jenkins, N.E.; Prior, C. Growth and formation of true conidia by Metarhizium flavoviride in a simple liquid medium. Mycol. Res. 1993, 97, 1489-1494. [CrossRef]

66. McClatchie, G.V.; Moore, D.; Bateman, R.P.; Prior, C. Effects of temperature on the viability of the conidia of Metarhizium flavoviride in oil formulations. Mycol. Res. 1994, 98, 749-756.

67. Moore, D.; Douro-Kpindou, O.-K.; Jenkins, N.E.; Lomer, C.J. Effects of moisture content and temperature on storage of Metarhizium flavoviride conidia. Biocontrol Sci. Technol. 1996, 6, 51-62. [CrossRef]

68. Barnes, S.E.; Moore, D. The effect of fatty, organic or phenolic acids on the germination of conidia of Metarhizium flavoviride. Mycol. Res. 1997, 101, 662-666. [CrossRef]

69. Moore, D.; Higgins, P.M. Viability of stored conidia of Metarhizium flavoviride Gams and Rozsypal, produced under differing culture regimes and stored with clays. Biocontrol Sci. Technol. 1997, 7, 335-344. [CrossRef]

70. Fargues, J.; Smits, N.; Vidal, C.; Vey, A.; Vega, F.; Mercadier, G.; Quimby, P. Effect of liquid culture media on morphology, growth, propagule production, and pathogenic activity of the Hyphomycete, Metarhizium flavoviride. Mycopathologia 2002, 154, 127-138. [CrossRef]

71. Issaly, N.; Chauveau, H.; Aglevor, F.; Fargues, J.; Durand, A. Influence of nutrient, $\mathrm{pH}$ and dissolved oxygen on the production of Metarhizium flavoviride Mf189 blastospores in submerged batch culture. Process Biochem. 2005, 40, 1425-1431. [CrossRef]

72. Roberts, D.W.; St Leger, R.J. Metarhizium spp., cosmopolitan insect-pathogenic fungi: Mycological aspects. In Advances in Applied Microbiology; Laskin, A.I., Bennett, J.W., Gadd, G., Eds.; Elsevier Inc.: London, UK, 2004; pp. 1-70.

73. Moore, D.; Bridge, P.D.; Higgins, P.M.; Bateman, R.P.; Prior, C. Ultra-violet radiation damage to Metarhizium flavoviride conidia and the protection given by vegetable and mineral oils and chemical sunscreens. Ann. Appl. Biol. 1993, 122, 605-616. [CrossRef]

74. Bateman, R.P.; Carey, M.; Moore, D.; Prior, C. The enhanced infectivity of Metarhizium flavoviride in oil formulations to desert locusts at low humidities. Ann. Appl. Biol. 1993, 122, 145-152. [CrossRef]

75. Ball, B.V.; Pye, B.J.; Carreck, N.L.; Moore, D.; Bateman, R.P. Laboratory testing of a mycopesticide on non-target organisms: The effects of an oil formulation of Metarhizium flavoviride applied to Apis mellifera. Biocontrol Sci. Technol. 1994, 4, 289-296. [CrossRef]

76. Hunt, T.R.; Moore, D.; Higgins, P.M.; Prior, C. Effect of sunscreens, irradiance and resting periods on the germination of Metarhizium flavoviride conidia. Entomophaga 1994, 39, 313-322. [CrossRef]

77. Sabbour, M.M. The toxicity effect of nano fungi Isaria fumosorosea and Metarhizium flavoviride against the potato tuber moth, Phthorimaea operculella (Zeller). Am. J. Biol. Life Sci. 2015, 3, 155-160.

78. Sabbour, M.M.; Singer, S.M. Efficacy of nano Isaria fumosorosea and Metarhizium flavoviride against corn pests under laboratory and field conditions in Egypt. Int. J. Sci. Res. ISSN 2015, 4, 2319-7064.

79. Aguda, R.M.; Rombach, M.C.; Im, D.J.; Shepard, B.M. Suppression of populations of the brown planthopper, Nilaparvata lugens (StÅl) (Hom.; Delphacidae) in field cages by entomogenous fungi (Deuteromycotina) on rice in Korea. J. Appl. Entomol. 1987, 104, 167-172. [CrossRef]

80. Moore, D.; Reed, M.; le Patourel, G.; Abraham, Y.J.; Prior, C. Reduction of feeding by the desert locust, Schistocerca gregaria, after infection with Metarhizium flavoviride. J. Invertebr. Pathol. 1992, 60, 304-307. [CrossRef]

81. Moorhouse, E.R.; Gillespie, A.T.; Charnley, A.K. Laboratory selection of Metarhizium spp. isolates for control of vine weevil larvae (Otiorhynchus sulcatus). J. Invertebr. Pathol. 1993, 62, 15-21. [CrossRef]

82. Milner, R.J.; Prior, C. Susceptibility of the Australian plague locust, Chortoicetes terminifera, and the wingless grasshopper, Phaulacridium vittatum, to the fungi Metarhizium spp. Biol. Control 1994, 4, 132-137. [CrossRef]

83. Seyoum, E.; Moore, D.; Charnley, A.K. Reduction in flight activity and food consumption by the desert locust, Schistocerca gregaria Forskål (Orth., Cyrtacanthacrinae), after infection with Metarhizium flavoviride. J. Appl. Entomol. 1994, 118, 310-315. [CrossRef] 
84. Prior, C.; Carey, M.; Abraham, Y.J.; Moore, D.; Bateman, R.P. Development of a bioassay method for the selection of entomopathogenic fungi virulent to the desert locust, Schistocerca gregaria (Forskål). J. Appl. Entomol. 1995, 119, 567-573. [CrossRef]

85. Caudwell, R.W.; Gatehouse, A.G. Laboratory and field trials of bait formulations of the fungal pathogen, Metarhizium flavoviride, against a tropical grasshopper and locust. Biocontrol Sci. Technol. 1996, 6, 561-568. [CrossRef]

86. Moore, D.; Bateman, R.P.; Carey, M.; Prior, C. Long-term storage of Metarhizium flavoviride conidia in oil formulations for the control of locusts and grasshoppers. Biocontrol Sci. Technol. 1995, 5, 193-200. [CrossRef]

87. Milner, R.J.; Staples, J.A.; Prior, C. Laboratory susceptibility of Locusta migratoria (L.), Austracrisguttulosa (Walker) and Valanga irregularis (Walker) (Orthoptera: Acrididae) to an oil formulation of Metarhizium flavoviride Gams and Rozsypal (Deuteromycotina: Hyphomycetes). Aust. J. Entomol. 1996, 35, 355-360. [CrossRef]

88. Fargues, J.; Ouedraogo, A.; Goettel, M.S.; Lomer, C.J. Effects of temperature, humidity and inoculation method on susceptibility of Schistocerca gregaria to Metarhizium flavoviride. Biocontrol Sci. Technol. 1997, 7, 345-356. [CrossRef]

89. Peveling, R.; Demba, S.A. Virulence of the entomopathogenic fungus Metarhizium flavoviride Gams and Rozsypal and toxicity of diflubenzuron, fenitrothion-esfenvalerate and profenofos-cypermethrin to nontarget arthropods in Mauritania. Arch. Environ. Contam. Toxicol. 1997, 32, 69-79. [CrossRef] [PubMed]

90. Rangel, D.E.N.; Braga, G.U.L.; Fernandes, É.K.K.; Keyser, C.A.; Hallsworth, J.E.; Roberts, D.W. Stress tolerance and virulence of insect-pathogenic fungi are determined by environmental conditions during conidial formation. Curr. Genet. 2015, 61, 383-404. [CrossRef] [PubMed]

91. Langewald, J.; Kooyman, C.; Douro-Kpindou, O.; Lomer, C.J.; Dahmoud, A.O.; Mohamed, H.O. Field treatment of desert locust (Schistocerca gregaria Forskal) hoppers in Mauritania using an oil formulation of the entomopathogenic fungus Metarhizium flavoviride. Biocontrol Sci. Technol. 1997, 7, 603-612. [CrossRef]

92. Damin, S.; Vilani, A.; de Freitas, D.; Krasburg, C.; de Queiroz, J.A.; Kagimura, F.Y.; Onofre, S.B. Ação de fungicidas sobre o crescimento do fungo entomopatogênico Metarhizium sp. Rev. Acad. Ciênc. Anim. 2011, 9, 41-49. [CrossRef]

93. Sammaritano, J.A.A.; Lastra, C.C.L.; Leclerque, A.; Vazquez, F.; Toro, M.E.; D'Alessandro, C.P.; Cuthbertson, A.G.S.; Lechner, B.E. Control of Bemisia tabaci by entomopathogenic fungi isolated from arid soils in Argentina. Biocontrol Sci. Technol. 2016, 26, 1668-1682. [CrossRef]

94. Jarmuł-Pietraszczyk, J.; Kamionek, M.; Wilkowski, P. Effect of long fertilisation on seasonal variability of occurrence of entomopathogenic nematodes and fungi. Ecol. Chem. Eng. A 2011, 18, 359-363.

95. Meyling, N.V.; Thorup-Kristensen, K.; Eilenberg, J. Below-and aboveground abundance and distribution of fungal entomopathogens in experimental conventional and organic cropping systems. Biol. Control 2011, 59, 180-186. [CrossRef]

96. Hong, T.D.; Jenkins, N.E.; Ellis, R.H. The effects of duration of development and drying regime on the longevity of conidia of Metarhizium flavoviride. Mycol. Res. 2000, 104, 662-665. [CrossRef]

97. Onofre, S.B.; Miniuk, C.M.; de Barros, N.M.; Azevedo, J.L. Growth and sporulation of Metarhizium flavoviride var. flavoviride on culture media and lighting regimes. Sci. Agric. 2001, 58, 613-616. [CrossRef]

98. Stathers, T.E.; Moore, D.; Prior, C. The effect of different temperatures on the viability of Metarhizium flavoviride conidia stored in vegetable and mineral oils. J. Invertebr. Pathol. 1993, 62, 111-115. [CrossRef]

99. Morley-Davies, J.; Moore, D.; Prior, C. Screening of Metarhizium and Beauveria spp. conidia with exposure to simulated sunlight and a range of temperatures. Mycol. Res. 1996, 100, 31-38. [CrossRef]

100. Shah, P.A.; Douro-Kpindou, O.K.; Sidibe, A.; Daffe, C.O.; van der Pauuw, H.; Lomer, C.J. Effects of the sunscreen oxybenzone on field efficacy and persistence of Metarhizium flavoviride conidia against Kraussella amabile (Orthoptera: Acrididae) in Mali, West Africa. Biocontrol Sci. Technol. 1998, 8, 357-364. [CrossRef]

101. Fernandes, É.K.K.; Rangel, D.E.N.; Braga, G.U.L.; Roberts, D.W. Tolerance of entomopathogenic fungi to ultraviolet radiation: A review on screening of strains and their formulation. Curr. Genet. 2015, 61, 427-440. [CrossRef]

102. Soares, G.G.; Marchal, M.; Ferron, P. Susceptibility of Otiorhynchus sulcatus (Coleoptera: Curculionidae) larvae to Metarhizium anisopliae and Metarhizium flavoviride (Deuteromycotina: Hyphomycetes) at two different temperatures. Environ. Entomol. 1983, 12, 1887-1891. [CrossRef] 
103. Price, R.E.; Bateman, R.P.; Brown, H.D.; Butler, E.T.; Müller, E.J. Aerial spray trials against brown locust (Locustana pardalina, Walker) nymphs in South Africa using oil-based formulations of Metarhizium flavoviride. Crop Prot. 1997, 16, 345-351. [CrossRef]

104. Inglis, G.D.; Johnson, D.L.; Cheng, K.-J.; Goettel, M.S. Use of pathogen combinations to overcome the constraints of temperature on entomopathogenic Hyphomycetes against grasshoppers. Biol. Control 1997, 8, 143-152. [CrossRef]

105. Thomas, M.B.; Jenkins, N.E. Effects of temperature on growth of Metarhizium flavoviride and virulence to the variegated grasshopper, Zonocerus variegatus. Mycol. Res. 1997, 101, 1469-1474. [CrossRef]

106. Thomas, M.B.; Blanford, S.; Lomer, C.J. Reduction of feeding by the variegated grasshopper, Zonocerus variegatus, following infection by the fungal pathogen, Metarhizium flavoviride. Biocontrol Sci. Technol. 1997, 7, 327-334. [CrossRef]

107. Moore, D.; Langewald, J.; Obognon, F. Effects of rehydration on the conidial viability of Metarhizium flavoviride mycopesticide formulations. Biocontrol Sci. Technol. 1997, 7, 87-94. [CrossRef]

108. Sieglaff, D.H.; Pereira, R.M.; Capinera, J.L. Microbial control of Schistocerca americana (Orthoptera: Acrididae) by Metarhizium flavoviride (Deuteromycotina): Instar dependent mortality and efficacy of ultra low volume application under greenhouse conditions. J. Econ. Entomol. 1998, 91, 76-85. [CrossRef]

109. Inglis, G.D.; Duke, G.M.; Kawchuk, L.M.; Goettel, M.S. Influence of oscillating temperatures on the competitive infection and colonization of the migratory grasshopper by Beauveria bassiana and Metarhizium flavoviride. Biol. Control 1999, 14,111-120. [CrossRef]

110. Jin, S.-F.; Feng, M.-G.; Chen, J.-Q. Selection of global Metarhizium isolates for the control of the rice pest Nilaparvata lugens (Homoptera: Delphacidae). Pest Manag. Sci. 2008, 64, 1008-1014. [CrossRef] [PubMed]

111. Rocha, L.F.N.; Luz, C. Activity of Metarhizium spp. and Isaria spp. from the Central Brazilian Cerrado against Triatoma infestans nymphs. Trans. R. Soc. Trop. Med. Hyg. 2011, 105, 417-419. [CrossRef] [PubMed]

112. Li, M.; Lin, H.; Li, S.; Chen, P.; Jin, L.; Yang, J. Virulence of entomopathogenic fungi to adults and eggs of Nilaparvata lugens Stal (Homopera: Delphacidae). Afr. J. Agric. Res. 2012, 7, 2183-2190.

113. Gorashi, N.E.; Elhassan, S.M.; Bashir, M.O. The effect of Metarhizium flavoviride and phenylacetonitrile on food consumption and the daily behavior of the gregarious nymphs of Schistocerca gregaria. Int. J. Agric. Innov. Res. 2014, 2, 919-922.

114. Lee, W.W.; Shin, T.Y.; Bae, S.M.; Woo, S.D. Screening and evaluation of entomopathogenic fungi against the green peach aphid, Myzus persicae, using multiple tools. J. Asia Pac. Entomol. 2015, 18, 607-615. [CrossRef]

115. Huanhuan, Z.; Yang, C.; Pinjun, W.; Weixia, W.; Fengxiang, L.; Qiang, F. Influence of symbiotic bacteria arsenophonus, rice variety and temperature on the incidence rate of Nilaparvata lugens to Metarhizium flavoviride. Chin. J. Rice Sci. 2017, 31, 643-651.

116. Kryukov, V.; Yaroslavtseva, O.; Tyurin, M.; Akhanaev, Y.; Elisaphenko, E.; Wen, T.-C.; Tomilova, O.; Tokarev, Y.; Glupov, V. Ecological preferences of Metarhizium spp. from Russia and neighboring territories and their activity against Colorado potato beetle larvae. J. Invertebr. Pathol. 2017, 149, 1-7. [CrossRef]

117. Dogan, Y.O.; Hazir, S.; Yildiz, A.; Butt, T.M.; Cakmak, I. Evaluation of entomopathogenic fungi for the control of Tetranychus urticae (Acari: Tetranychidae) and the effect of Metarhizium brunneum on the predatory mites (Acari: Phytoseiidae). Biol. Control 2017, 111, 6-12. [CrossRef]

118. Douro-Kpindou, O.-K.; Godonou, I.; Houssou, A.; Lomer, C.J.; Shah, P.A. Control of Zonocerus variegatus by ultra-low volume application of an oil formulation of Metarhizium flavoviride conidia. Biocontrol Sci. Technol. 1995, 5, 131-139. [CrossRef]

119. de Castro, T.R. Abundance, Genetic Diversity and Persistence of Metarhizium spp. Fungi from Soil of Strawberry Crops and Their Potential as Biological Control Agents against the Two-Spotted Spider Mite Tetranychus urticae. Ph.D. Thesis, University of Copenhagen, Copenhagen, Denmark, 2016.

120. Smits, J.E.; Johnson, D.L.; Lomer, C. Pathological and physiological responses of ring-necked pheasant chicks following dietary exposure to the fungus Metarhizium flavoviride, a biocontrol agent for locusts in africa. J. Wildl. Dis. 1999, 35, 194-203. [CrossRef] [PubMed]

(C) 2019 by the authors. Licensee MDPI, Basel, Switzerland. This article is an open access article distributed under the terms and conditions of the Creative Commons Attribution (CC BY) license (http://creativecommons.org/licenses/by/4.0/). 